\title{
ON-FARM PRODUCTION AND PROCESSING OF SELECTED \\ COCONUT SAP-BASED NATURAL AND NUTRITIOUS FOOD PRODUCTS FROM SCTNP SCHEME
}

\author{
Millicent I. Secretaria ${ }^{1}$, Raul M. Ebuna ${ }^{2}$, and Severino S. Magat ${ }^{3}$
}

\begin{abstract}
The processing of coconut sap produced from the sequential coconut toddy and nut production (SCTNP) scheme was conducted at the Philippine Coconut Authority Zamboanga Research Center, San Ramon, Zamboanga City from 1997 and 1999-2001 to determine their acceptability to local community members and evaluate their economic profitability.

The processing of coconut sap into food products such as fresh sap beverage, coconut syrup, sugar and vinegar involves simple procedures at the farmer's level. These sap-based food products proved to be highly acceptable in terms of their nutritional and economic values. They are rich in total solids, sugar (sucrose), protein, carbohydrates, phosphorus and amino acids. Coconut-sap sugar contains high amounts of essential elements such as $\mathrm{N}, \mathrm{P}, \mathrm{K}, \mathrm{Mg}, \mathrm{Cl}$ and $\mathrm{S}$ and micronutrients $(\mathrm{B}, \mathrm{Zn}, \mathrm{Fe}, \mathrm{Cu})$ compared to brown cane sugar and refined white sugar(almost without micronutrient). The production of sap beverage, syrup and vinegar showed higher farmer's net income (PhP14,800 - 9,100/month) and return on investment-ROI (465\%-380\%) compared to sugar making (PhP 5,900/month, 278\% ROI).

On-farm production and processing of coconut sap-based food products have both social and economic advantages. This technology offers bigger opportunity for farmers to increase their income and generate employment especially to family members. Likewise, this product diversification scheme can promote multi-uses and competitiveness of the coconut palm.
\end{abstract}

Keywords: Coconut sap, processing, sap-based food products, diversification

1 Science Research Specialist II \& Scientist I, Philippine Coconut Authority-Davao Research Center, Bago Oshiro, Davao City, Philippines

2 Sciece Research Specialist Ii, PCA-Zamboanga Research Centre, San Ramon, Zamboanga City, Philippines

3 Career Scientist IV, Dept. of Agriculture/Philippine Coconut Authority, Research, Development and Extension Branch, Diliman Quezon Cit, Philippines. 


\section{INTRODUCTION}

The coconut tree popularly known as the 'tree of life' is characteristically a food supplier from its fruit, inflorescence and other edible parts throughout the year. The inflorescence of this palm is a source of many food products, its unopened spathe can be tapped to produce sap for coconut beverage, vinegar, syrup or 'honey', sugar and even wine while its fertilized flowers or fruit can produce coconut meat, milk, cream oil, water, flour, desiccated coconut, chips and nata de coco.

The coconut sap, tapped from unopened inflorescence or spathe can be produced from coconut full toddy scheme or from a production technology known 'Sequential coconut toddy and nut production (SCTNP) scheme (Maravilla and Magat, 1991). The technology provides early income (from coconut sap) to coconut farmers before the copra can be obtained, while the inflorescence is still close and female flowers are still developing. This scheme has been successfully done in 'Laguna' tall and Malayan yellow dwarf $x$ West African tall ('MAWA') hybrid coconuts and proved feasible and profitable (Maravilla and Magat, 1993). Likewise, its application has been proven more profitable in local hybrids such as Catigan dwarf $\mathrm{x}$ Laguna tall (CATD x LAGT), Malayan red dwarf x Baybay tall (MRD x BAYT) and MRD x Tagnanan tall (Secretaria et al., 2001; 2002).

The conversion of coconut into copra is the most popular on-farm processing activity in local coconut-growing communities in the country. While it is possible to produce diverse products from coconut, our coconut farmers, in general have not adopted the other known processing technologies at the farmer's level. The coconut sap as an important coconut product could be processed into diverse natural food products using simple and easy procedures. In countries (e.g. Thailand, Indonesia and India) where coconut sugar production is already developed, production and marketing are well organized in the cooperative sector (Thampan, 1996). Thus, it is feasible for small coconut farmers to undertake the required processing right at their fields. Diversification of coconut products is very beneficial to local coconut farmers as it will increase farm productivity and income of coconut farmers and workers.
This paper presents the simple processing procedures of coconut sap-based food products such as coconut sap drink (beverage), syrup ('honey' or nectar), sugar and vinegar and its acceptability to consumers in the local community. This was a component of the completed project entitled 'Varietal response of various coconut hybrids and cultivars to sequential coconut toddy and nut production (SCTNP) scheme' conducted at the PCA-Zamboanga Research Center, Zamboanga City from April-December 1997 (phase 1) and April,1999 to September 2001 (phase 2). It also aims to determine the economic profitability of the produced sap-based foodproducts.

\section{MATERIAL AND METHODS}

\subsection{Tapping and harvesting of coconut sap}

Coconut sap was tapped form coconut trees from three local dwarf $\mathrm{x}$ tall hybrids Catigan dwarf $\mathrm{x}$ Laguna tall - CATD x LAGT, Malayan red dwarf x Tagnanan tall - MRD x TAGT, Malayan red dwarf x Baybay tall -MRD x BAYT) and one tall cultivar (LAGT) using the sequential coconut toddy and nut production (SCTNP) scheme (Fig. 1) as described in Maravilla and Magat (1993) in contrast to the traditional full toddy tapping scheme (Fig 2). In both schemes, harvesting of coconut sap/toddy could be done twice a day:

a) Morning (before 8 A.M.) for the production of 'tuba' or vinegar;

b) b) Afternoon (not later than 3 P.M.) toddy produced is sweeter than that of the morning, thus is used for fresh sap drink and syrup/sugar making.

\subsection{Processing of coconut sap food products}

As coconut sap is highly perishable due to the yeast microflora, the harvested sap (filtered thru netted cloth) and intended for beverage, syrup and sugar should be processed by boiling for $1 / 2$ hour in a large cast iron pan (Levang, 1988). This process prevents the sap from fermentation.

All tools and containers should be clean at all times. A little amount of lime $(\mathrm{CaO})$ was added to the receptacle to prevent the sap from 
fermentation. The materials and equipment needed for processing of coconut sap by-products were :

- Materials: large or medium size iron cast pan, wide large plastic container, netted cloth, $350 \mathrm{ml}$ plastic cups or bottles, glass bottles with cover or seal, plastic packaging material, plastic sealing material, wooden utensil (spatula), wood or charcoal fuel.

- Equipment: Cooking furnace, refrigerator, plastic sealer machine (optional)

The procedures for processing coco sap byproducts were as follows:

\section{Fresh sap drink (Fig. 3 )}

- Boil fresh harvested sap for $1 / 2$ hour in a large iron pan.

- Allow the boiled sap to cool, then pour separately in desired container (usually 350 ml. plastic cups or bottles), seal tightly and place in a refrigerator (freezer). If hygienically prepared, the sap drink could be stored until three (3) days without deterioration .

2. Coconut sap vinegar (Fig. 4)

- Pour freshly harvested sap in a wide large plastic container with netted cloth to allow aeration, prevent entrance of dirt and foreign objects.

- After 10-14 days fermentation in a well ventilated room, the sap is transformed to a new product, natural sap vinegar.

- The vinegar is pasteurized by heating for 510 minutes at $60-65^{\circ} \mathrm{C}$ to maintain the desired quality of vinegar (with at least $4 \%$ acidity).

- Allow the vinegar to cool before placing in very clean bottles with tight sealed cover.

3. Coconut syrup (nectar or 'honey') - Fig. 5

- Boil freshly harvested sap for $1 / 2$ hour in a large iron pan.

- Continue boiling of sap until it reaches $110^{\circ} \mathrm{C}$ temperature or sticky under a moderate to very low heat (color of sap changes to yellow orange).
- Allow the coconut syrup (honey-like and sticky liquid) to cool, then pour into a desired container.

4.a Coconut sugar (small volume of coconut sap 4 1) - Fig. 6

- Boil freshly harvested sap for $1 / 2$ hour in a large iron pan.

- Continue boiling of coconut sap to evaporate the water under moderate heat with occasional stirring until the liquid thickens at $115^{\circ} \mathrm{C}$.

- Remove the pan with boiling sap from the flame when it becomes sticky.

- Continue mixing the sap until it becomes granular.

- Air-dry the coconut sugar (pale brown, sweet with distinct coconut aroma) before placing them in plastic packaging material. Seal tightly using a plastic sealer machine (if available) or with a cellophane tape.

4.b Coconut sugar (big volume of coco sap [30 liters] -Fig. 7) based on Naka (1996)

- Pour the afternoon collected sap into a dryclean large iron pan and immediately boil.

- During evaporation, stirring has to be done occasionally. Discard the foam formed in the surface as it would impart a burnt smell on the liquid.

- When excessive foam is formed, place an open-end bamboo basket in the pan so the sap will not spill out from it. Continue cooking at medium fire until a thick liquid is formed. When foaming subsides, remove the open-end basket from the pan.

- When the temperature of the liquid reaches $115^{\circ} \mathrm{C}$, maintain the temperature of the liquid at medium fire for about 30 minutes to 1 hour until it became very sticky. Then, remove the pan from the fire. A iron plunger is used to introduce more air to the liquid so that granulation would take place.

- When mixture assumes a solid form, continue stirring of the mixture using a wooden spatula. Stirring should be more 
vigorous until mixture will break into small granules. Cool the mixture.

- Transfer the granulated sugar into a flat surface pan to break the granules into smaller size using a wooden spatula. Air dry sugar at room temperature. When dry, it is now ready for packing using plastic packaging material, sealed with cellophane tape or by plastic sealer machine (if available).

An acceptability test of the sap-based food products was conducted with ZRC employees (male \& female) and some members of the ZRC Housing Compound San Ramon, Zamboanga City as respondents (12 persons per food product).

\section{RESULTS AND DISCUSSION}

\subsection{Acceptability test of sap-based food products}

Some significant results of the acceptability or organoleptic test of the coconut sap-based food products revealed that:

- Coconut sap vinegar produced was highly acceptable, comparable or even better in acid taste than the other commercial brands of vinegar.

- Fresh sap drink was acceptable to male respondents as well as to female ones but should be taken in smaller amounts only. Like buko juice, fresh sap drink has a high potential in the market especially with the present trend of utilizing natural drinks.

- Coconut syrup ('honey') initially produced (with sour taste) for the production of sugar

during the first phase of the project was further tested in the $2^{\text {nd }}$ phase following the procedure indicated in the Techno Guide Sheet No. 8. To date, a better quality and acceptable coconut syrup and sugar have been produced from the SCTNP-produced coconut sap.

Based on the results of the acceptability test, it showed that coconut sap can be an alternative source of sugar/syrup and beverage and vinegar. The production of these cocosap-based food products shows their high potential for multi-uses as natural healthy and exotic drinks, use in jam jellies, marmalades and confectionaries (Masa, 2001).

Among these food products, coconut sugar shows higher potential for economic gains. Although labor intensive and time consuming, the coconut sugar industry (from cocosap) is highly profitable compared to nut/copra production $(115 \%$ in terms of farmer's gross income based on Thailand experience (Naka, 1996). Unlike in our country where coconut sugar industry is not yet developed, coconut sugar is already an export commodity in Thailand, (Naka, 1996) and commonly produced in coconut-growing communities in Indonesia and India (Thampan, 1996).

\subsection{Nutritional value of the sap-based food products}

As people are now becoming health conscious and are inclined towards consuming natural products instead of synthetic ones, the processing of cocosap-based food products provides for nutritious natural food products as freshly gathered coconut sap has high total sugar, calories, carbohydrates, ascorbic acid, phosphorus, (Naka, 1996 - Table 1) rich in amino acids (Kosaki and Sanchez, 1974 -Table 2) Coconut sap contains $17.5 \%$ total solids, $0.40 \%$ ash and $16 \%$ sucrose (Gibbs, 1911).

In fresh coconut sap, sugar is a major component after water, ranging from 16.1-18.99 $\mathrm{g} / 100 \mathrm{ml}$ (Naka, 1996). It is composed only of sucrose. Gibbs (1911) reported that the sucrose content of coconut sap is comparable with that of sugar cane, sugar beet, nipa (Nipa fructicans, Wurmb), buri (Croypha slate, Roxb) and kaong (Arenga saccharifers, Labill).

\subsection{Chemical and physical analyses of sap-based food products}

The chemical and physical analysis conducted by the Department of Science and TechnologyRegion XI, Zamboanga City on the coconut sap and sap-based food products revealed that the fresh coco sap contains more sucrose than the cocosap-based products (Table 3). However, cocosap-based food products contain more $\%$ total solids, reducing sugars, crude protein and ash indicating that these food products are nutritious and healthy, thus are good for our body. The coconut-sap sugar as compared to brown cane 
sugar and refined sugar contains higher amounts of nitrogen $(\mathrm{N})$, phosphorus $(\mathrm{P})$ potassium $(\mathrm{K})$, chlorine $(\mathrm{Cl})$, magnesium $(\mathrm{Mg})$, sulfur $(\mathrm{S})$ and micronutrients (boron-B, zinc-Zn, iron-Fe, cupper$\mathrm{Cu})$ than either brown cane sugar or refined white sugar (almost without micronutrient) as reflected in the chemical analysis done by the PCA Plant Tissue Analysis Laboratory (Magat, 2002-Table 4).

\subsection{Cost and return analysis of sap-based food products}

A simple cost and return analysis on a monthly basis of cocosap and its food by-products shows higher net income (PhP 9,100 $14,800 /$ month) and return on investment (ROI) on the production of vinegar, syrup and sap beverage with $388 \%, 380 \%$ and $465 \%$, respectively, compared sugar (Table. 5). Although the return on investment of selling fresh sap product without processing is just the same as that of vinegar and syrup, it is still advisable to process sap-based food products since these food products could be used for cooking, desserts and curries and some as raw material (syrup and sugar) for food industries e.g. confectionery. Hence, high value food products should be produced for the promotion of multi-uses and competitive-ness of the coconut palm. The technology offers bigger opportunity for coconut farmers for increased farm income and generation of employment to family members (processors) and farm workers (tappers).

\section{SUMMARY AND CONCLUSION}

The processing of coconut sap for the production of natural and nutritious sap-based food products involves very simple procedures. Since the procedures for processing can be done at farmers' level, the technology could provide employment opportunities to family members especially to women members.

The food products produced were highly acceptable to the local community members in terms of its nutritional value. These products are rich in nutrients needed by our body such as sugar, protein, carbohydrates, amino acids. Coconut sugar has higher amounts essential elements i.e. $\mathrm{N}, \mathrm{P}, \mathrm{K}, \mathrm{Cl}, \mathrm{Mg}, \mathrm{S}$ than brown cane sugar and refined white sugar. Furthermore, processing of sap-based food products could provide for additional income to the farmers as more coconut products are produced and marketed. Higher farmer's net income (PhP14,800 - 9,100/month) and return on investment-ROI (465-380\%) can be obtained from the processing of sap beverage, syrup and vinegar than sugar (PhP 5,900/month and $278 \%$ ROI)

\section{IMPLICATION AND RECOMMENDATION}

Realizing the significant social and economic benefits that can be derived from this sap-based food processing technology, it is therefore recommended that farmers should be encouraged to diversify their production to natural, high value and nutritious food products (beverage, syrup, sugar and vinegar) from coconut sap/toddy in additional to nut/copra based, fresh nut-based, shell-based, coir -based high value products. However, there should be available market for toddy and its by-products for this product diversification scheme to prosper. In this way, the promotion of multi-uses and competitiveness of coconut palm as the 'tree of life' will be achieved.

\section{ACKNOWLEDGEMENT}

With sincere appreciation and gratitude, the authors wish to expressed their heartfelt thanks to the following:

To the PCA Management, Former Administrators Virgilio M. David, Eduardo U. Escueta, Deputy Administrator Carlos B. Carpio and former Department Manager of DRC, Romero C. Blancaver for endorsing this research project to the United Nations Agency for International Development (USAID) thru National Development and Economic Authority - Technical Resource Project (NEDA-TRP) and the Department of Agriculture- Bureau of Agricultural Research (DA-BAR) for the funding support of the Phase 1 and 2 of this research project, respectively and for the needed support during the conduct of the project;

To Mr. Rogaciano Z. Margate, Scientist III and Division Chief III of Agronomy \& Soils Division, PCA-DRC for his valuable support to the project;

To the PCA-Zamboanga Research Center former and present Department Manager, Rodolfo 
M. Madrazo and Gerardo A. Santos, respectively; technical staff and field men who wholeheartedly supported in most of the activities of the project without them, this research undertaken may not be possible.

\section{LITERATURE CITED}

Gibbs, H.D. 1911. The Alcohol Industry of the Philippine Islands. Part I. Phil. Journal of Science Sec. A.6:97-206. In. Carandang, E.V. 2000. Potential of coconut sap-based sugar as high value organic food. Paper presented during the Millenium CocoWeek: A Symposium on the Current Trends and Prospects to Enhance the Coconut Industry. Aug. 29, 2000. PCA Auditorium, Quezon City.

Kosaki, M and P.C. Sanchez (1974) Studies on the tuba fermentation process. UPLB-IFST Annual Report. Los Banos, Laguna.

Levang, P. 1988. Coconut is also a sugar crop. Oleagineux. 43(4):1-2.

Magat, S.S. 1996. Intercropping and toddy/sugar production in coconut-based farming system: Possible integration with germplasm conservation and varietal improvement. In: Batugal, P.A., Ramanatha Rao and C. Bong (Editors) Proceedings of the Workshop on User's Perspective to promote multiuses and competitive of the coconut. Chumpon, Thailand. September 26-29, 1996.

Magat, S.S. 2002. Elemental content (ppm or mg/li) of three sources of edible sugar. (Compilation).

Maravilla, J.N. and S.S. Magat. 1991. Comparative response of hybrid and local tall coconut to nuttoddy production. In. Highlights '91. PCARRD Publication. $159 \mathrm{p}$.

Maravilla, J.N. and S.S. Magat. 1993. Sequential coconut toddy-nut production (SCTNP) in 'Laguna' tall variety and hybrid coconut. Paper presented (Best Paper Session) at the $9^{\text {th }}$ Annual Scientific Meeting of the Federation of Crop Science Societies of the Philippines (FCSSP). Aklan State College of Agriculture. Aklan. May. 1993. Also In: Phil. Journal of Coconut Studies XVIII (2) :7-15.
Masa, D.B. 2001. Traditional and emerging coconut products. Paper presented during the $1^{\text {st }} \quad$ National Coconut Congress. Royal Mandaya Hotel, Davao City. October 1819,2001.

Naka, P. 1996. Potential of producing sugar form coconut and requirement for varietal development. In: Batugal, P.A., Ramanatha Rao and C. Bong (Editors) Proceedings of the Workshop on Promoting multi- purpose uses and competitiveness of the coconut. September 26-29, 1996, Chumpon, Thailand.

Secretaria, M.I., R.M. Ebuna, S.S.Magat, J.N. Maravilla, G.A. Santos and G .B. Baylon. 2001. Performance of selected coconut varieties/hybrids under sequential coconut toddy and nut production scheme or SCTNP. Proceedings on the R\&D Symposium cum Consultative Dialogue with Industry Sectors. Coconut Week 2001 Celebration. August 22,

2001, PCA Auditorium, Diliman, Quezon City. Also In: Coconut Research and Development Journal XVIII (1): 12-28, 2002. Published by the Asian and Pacific Coconut Community, Jakarta, Indonesia.

Secretaria, M.I., R.M. Ebuna, S.S.Magat, J.N. Maravilla, G.A. Santos and G.B.Baylon. 2002. Varietal response of coconut to SCTNP scheme. Paper presented at the $32^{\text {nd }}$ Annual Scientific Conference/Meeting of the Crop Science Society of the Philippines. April 2326, 2002. Bohol Tropics Resort. Tagbilaran City, Bohol.

Thampan, P.K. 1996. On - farm production and utilization of coconut products. In: Batugal, P.A., Ramanatha Rao and C. Bong (Editors) Proceedings of the Workshop on promoting multi- purpose uses and competitiveness of the coconut. September 26-29, 1996, Chumpon, Thailand.

Techno Guide Sheet No. 8. 2000. Producing high value 'organic and green' foods from coconut sap at village level. Pamphlet produced by PCA-ARDB, DRC and ZRC. 


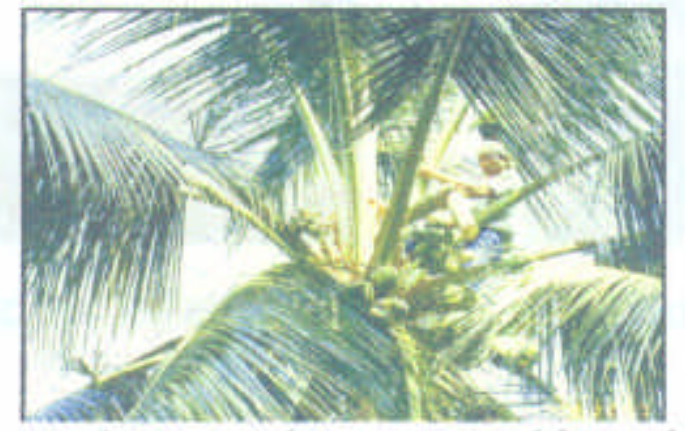

Fig 1 . Sequential coconut toddy and nut production (SCTNP) scheme

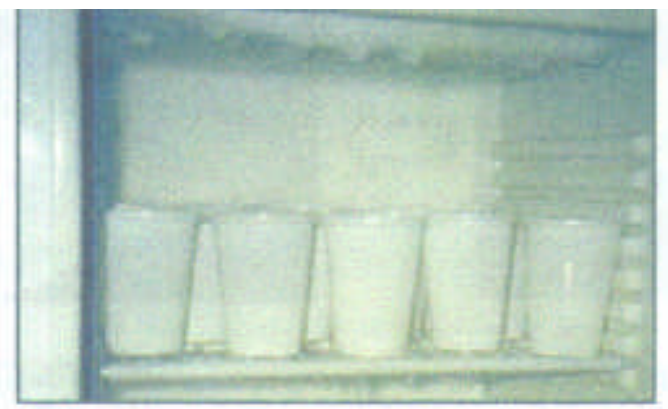

Fig. 3. Fresh sap drink (beverage)

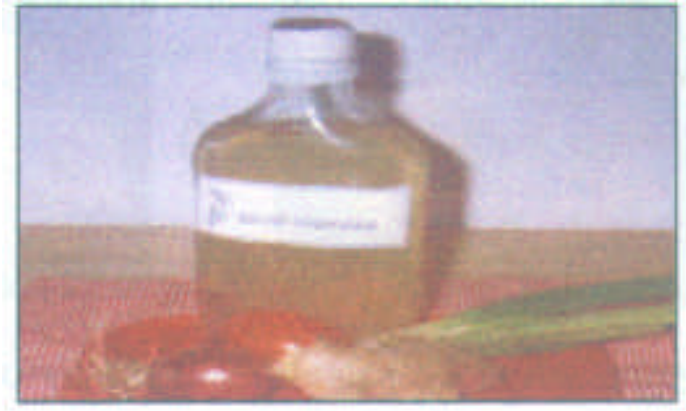

Fig. 4. Coconut vinegar

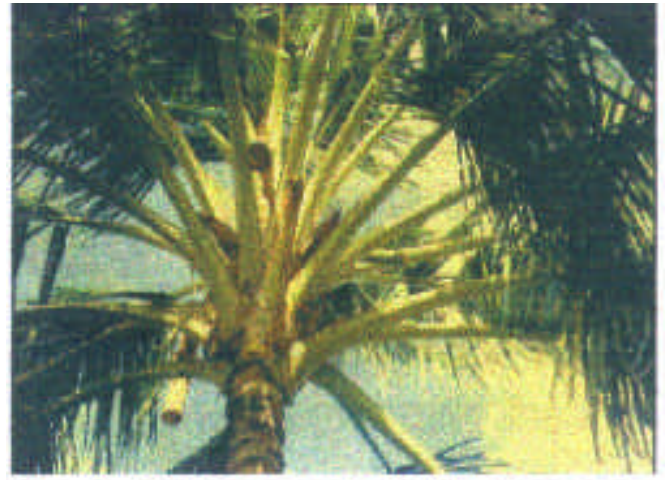

Fig. 2. Full coconut toddy tapping scheme 


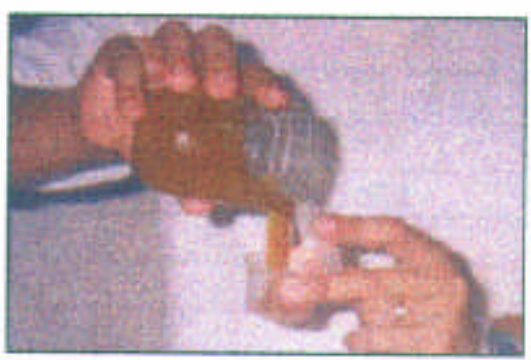

Fig. 5. Coconut syrup

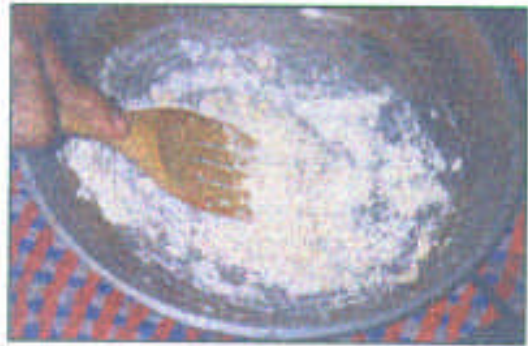

Fig. 6 Coconut sugar (small volume 4 ii)

Fig. 7. Processing of coconut sap (big volume - $30 \mathrm{ll}$ ) into sugar

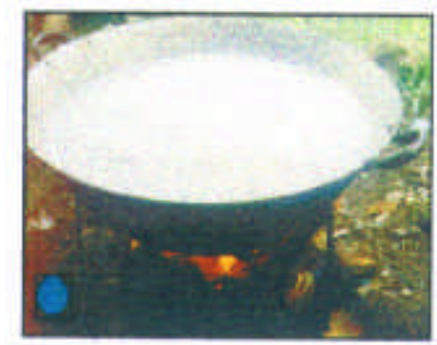

Boil sap immediately

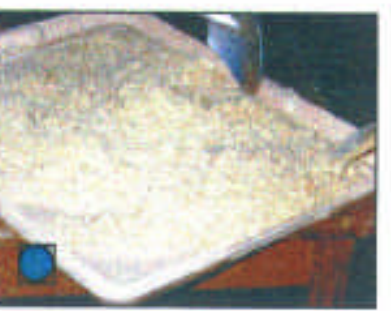

Break granules into smaller size

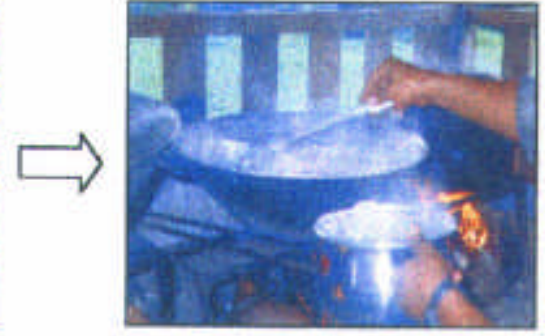

Discard formed foam

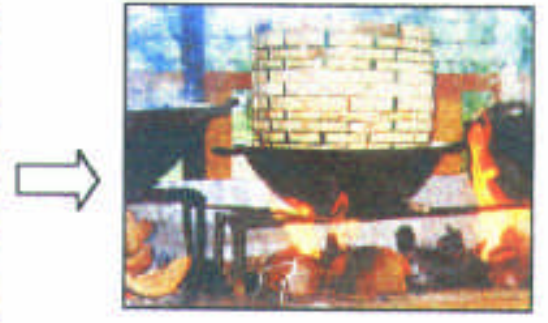

Place an open-end basket when excessive foam is produced<smiles>[LiH]</smiles>

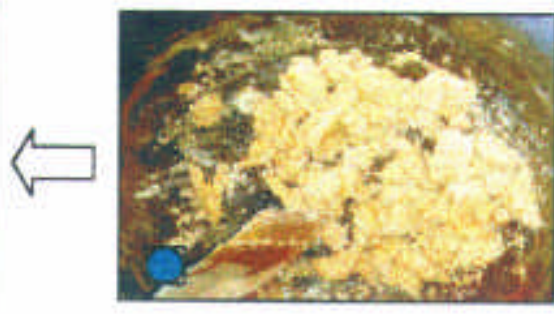

Vigorous stirring until mixture breaks into smaller granules

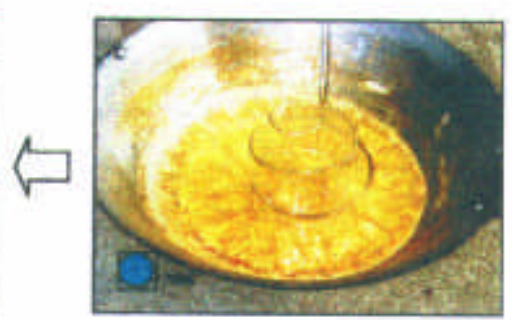

Use an iron plunger to introduce more air 
Table 1. Average chemical composition and nutritional value of coconut sap (Naka, 1996)

\begin{tabular}{|l|c|}
\hline Property & Value (per 100 g or ml) \\
\hline $\mathrm{pH}$ & 5.75 \\
\hline Total sugar (\%) mainly sucrose & $18.09 \mathrm{gm}$ \\
\hline Water & $87.5 \mathrm{ml}$ \\
\hline Calories & 48.0 joule \\
\hline Carbohydrate & $11.4 \mathrm{~g}$ \\
\hline Protein & $0.22 \mathrm{~g}$ \\
\hline Fat & $0.40 \mathrm{~g}$ \\
\hline Ca & $0.40 \mathrm{mg}$ \\
\hline Phosphorus & $20.0 \mathrm{mg}$ \\
\hline Iron & $0.18 \mathrm{mg}$ \\
\hline Thiamine & $0.016 \mathrm{mg}$ \\
\hline Riboflavin & $0.006 \mathrm{mg}$ \\
\hline Niacin & $0.48 \mathrm{mg}$ \\
\hline Ascorbic Acid & $20.6 \mathrm{mg}$ \\
\hline
\end{tabular}

Table 2. Amino acid content of freshly-gathered coconut sap (Kozaki \& Sanchez (1974)

\begin{tabular}{|l|c|}
\hline Amino acid & Value (g/100g) \\
\hline Trytophan & 1.27 \\
\hline Lysine & 0.32 \\
\hline Histidine & 1.19 \\
\hline Arginine & 0.35 \\
\hline Aspartic acid & 11.22 \\
\hline Threonine & 15.36 \\
\hline Serine & 8.24 \\
\hline Glutamic acid & 34.20 \\
\hline Proline & 3.52 \\
\hline Glycine & 0.47 \\
\hline Alanine & 2.56 \\
\hline Isoleucine & 0.38 \\
\hline Leucine & 0.48 \\
\hline Tyrosine & 0.31 \\
\hline Phenylalanine & 0.78 \\
\hline
\end{tabular}


Table 3. Chemical and physical analysis ${ }^{1}(\%)$ of coconut sap and sap-based food products at PCA-ZRC, Zamboanga City, January 2000

\begin{tabular}{|l|c|c|c|c|l|l|c|}
\hline Product & Total solids & Sucrose & Red. sugar & Protein & Ash & pH & Acidity \\
\hline Fresh sap & 12.1 & 0.66 & 2.00 & 0.30 & 0.52 & 3.61 & 0.94 \\
\hline Vinegar & 5.4 & - & - & 0.12 & 0.46 & 3.11 & 2.31 \\
\hline Syrup & 79.5 & - & 7.88 & 1.28 & 1.97 & 5.43 & - \\
\hline Sugar & 98.3 & & 13.50 & 1.78 & 2.37 & 5.40 & - \\
\hline
\end{tabular}

${ }^{1}$ Conducted by the Department of Science \& Technology, Region IX, Zamboanga City

Table 4. Elemental content (ppm/mg/li) of three sources of edible sugar ${ }^{1}$

\begin{tabular}{|c|r|r|r|}
\hline Element/nutrient & $\begin{array}{l}\text { Coco-sap sugar } \\
\text { (Produced at ZRC) }\end{array}$ & $\begin{array}{c}\text { Brown cane } \\
\text { sugar }\end{array}$ & $\begin{array}{c}\text { Refined white } \\
\text { sugar }\end{array}$ \\
\hline $\mathrm{N}$ & 2,020 & 100 & 0 \\
\hline $\mathrm{P}$ & 790 & 30 & 0.7 \\
\hline $\mathrm{K}$ & 10,300 & 650 & 60 \\
\hline $\mathrm{Ca}$ & 60 & 240 & 10 \\
\hline $\mathrm{Mg}$ & 290 & 70 & 10 \\
\hline $\mathrm{Na}$ & 450 & 20 & 100 \\
\hline $\mathrm{Cl}$ & 4,700 & 180 & 20 \\
\hline $\mathrm{S}$ & 260 & 130 & 1.2 \\
\hline $\mathrm{B}$ & 6.3 & 0 & 0 \\
\hline $\mathrm{Zn}$ & 21.2 & 2 & 1.2 \\
\hline $\mathrm{Mn}$ & 1.3 & 2 & 0.6 \\
\hline $\mathrm{Fe}$ & 21.9 & 12.6 & \\
\hline $\mathrm{Cu}$ & 2.3 & 0.6 & \\
\hline
\end{tabular}

${ }^{1}$ Analyzed by the PCA-Plant Tissue Analysis Laboratory, 11 September 2000, compiled by S.S. Magat (2002) 
Table 5. SIMPLE COST AND RETURN ANALYSIS OF COCOSAP PRODUCTS, 2001 (from 30 trees per month production)

\begin{tabular}{|l|c|c|c|c|c|}
\hline & $\begin{array}{c}\text { Fresh } \\
\text { Sap }\end{array}$ & Vinegar & Sap Drink & Syrup & Sugar \\
\hline $\begin{array}{l}\text { Estimated harvest (30 } \\
\text { trees) - @ 2.0 1/tree }\end{array}$ & $601^{1}$ & $601^{1}$ & $601^{1}$ & $601^{1}$ & $601^{1}$ \\
\hline Recovery (\%) & 100 & 80 & 70 & 17 & 15 \\
\hline $\begin{array}{l}\text { Production - } \\
30 \text { trees/mo (l) }\end{array}$ & 1,800 & 1,440 & 1,260 & 306 & $270 \mathrm{~kg}$ \\
\hline $\begin{array}{l}\text { Suggested selling } \\
\text { price (PhP) }\end{array}$ & $5 / 1$ & $8 / 1$ & $5 / 350 \mathrm{ml}$ & $10 / 200 \mathrm{ml}$ & $30 / \mathrm{kg}$ \\
\hline Gross Income (PhP) & 9,000 & 11,520 & 18,000 & 15,500 & 8,100 \\
\hline Material Cost & 2,100 & 2,020 & 2,410 & 1,830 & 455 \\
\hline Processing Cost & - & 337.5 & 775 & 1,350 & $1,687.5$ \\
\hline Total Cost ${ }^{3}(\mathrm{PhP})$ & 2,100 & $2,357.5$ & 3,185 & 3,180 & $2,142.5$ \\
\hline Net Income (PhP) & 6,900 & $9,162.5$ & 14,815 & 12,120 & $5,957.5$ \\
\hline $\begin{array}{l}\text { Return on } \\
\text { investment }{ }^{4}(\%)\end{array}$ & 328 & 388 & 465 & 380 & 278 \\
\hline
\end{tabular}

${ }^{1}$ Assuming all total sap harvest from 30 trees is used for each food product

${ }^{2}$ From SCTNP-tapped trees

${ }^{3}$ Details of total cost indicated in Annex table 1

${ }^{4}$ Farmer/tapper uses his harvested coconut sap for processing of food products 
Annex Table 1. Details of total cost on processing of coconut sap-based food products

\begin{tabular}{|c|c|c|c|}
\hline Food Product/Item & No. of unit & $\begin{array}{c}\text { Cost/unit } \\
\text { (PhP) }\end{array}$ & $\begin{array}{l}\text { Total Cost } \\
\text { (PhP) }\end{array}$ \\
\hline $\begin{array}{l}\text { 1. Coconut Vinegar } \\
\text { Plastic bottles (1 lt capacity) } \\
\text { Large plastic container } \\
\text { Iron pan } \\
\text { Cloth/kitchen utensil } \\
\text { Wooden fuel } \\
\text { Sub-total } \\
\text { Labor * (processing -1hr/day) } \\
\text { Grand Total }\end{array}$ & $\begin{array}{c}1,440 \mathrm{pcs} \\
2 \mathrm{pcs} \\
1 \mathrm{pc} \\
1 \mathrm{pc} \\
3 \text { bundles }\end{array}$ & $\begin{array}{r}1.00 \\
150 \\
200 \\
50 \\
30\end{array}$ & $\begin{array}{c}1,440 \\
300 \\
200 \\
50 \\
30 \\
2,020 \\
337.5 \\
\mathbf{2 , 3 5 7 . 5}\end{array}$ \\
\hline $\begin{array}{l}\text { 2. Coconut fresh sap drink } \\
\text { Plastic cups with cover } \\
\text { Wooden fuel } \\
\text { Iron cast pan } \\
\text { Sub-total } \\
\text { Electric consumption/mo } \\
\text { Labor ( processing- } 2 \text { hrs/day) } \\
\text { Grand Total }\end{array}$ & $\begin{array}{l}3,600 \text { pcs } \\
5 \text { bundles } \\
1 \text { pc }\end{array}$ & $\begin{array}{l}30 / 50 \mathrm{pcs} \\
10 \\
200 \\
100\end{array}$ & $\begin{array}{c}2,160 \\
50 \\
200 \\
2,410 \\
100 \\
675 \\
\mathbf{3 , 1 8 0}\end{array}$ \\
\hline $\begin{array}{l}\text { 3. Coconut syrup } \\
\text { Glass bottles } \\
\text { Wooden fuel } \\
\text { Iron cast pan } \\
\text { Sub-total } \\
\text { Labor (processing }-4 \text { hrs/day) } \\
\text { Grand Total }\end{array}$ & $\begin{array}{l}1,530 \\
10 \text { bundles } \\
1 \mathrm{pc}\end{array}$ & $\begin{array}{l}1.00 \\
100 \\
200\end{array}$ & $\begin{array}{c}1,530 \\
100 \\
200 \\
1,830 \\
1,350 \\
\mathbf{3 , 1 8 0}\end{array}$ \\
\hline $\begin{array}{l}\text { 4. Coconut sugar } \\
\text { Plastic container ( } 6 \text { “x 9”) } \\
\text { Scotch tape } \\
\text { Wooden fuel } \\
\text { Iron cast pan } \\
\text { Bamboo basket } \\
\text { Sub-total } \\
\text { Labor (processing - } 5 \text { hrs/day) } \\
\text { Grand Total }\end{array}$ & $\begin{array}{l}300 \mathrm{pcs} \\
1 \mathrm{pc} \\
15 \text { bundles } \\
1 \mathrm{pc} \\
1 \mathrm{pc}\end{array}$ & $\begin{array}{l}15 / 100 \mathrm{pcs} \\
20 \\
10 \\
200 \\
40\end{array}$ & $\begin{array}{c}45 \\
20 \\
150 \\
200 \\
40 \\
455 \\
1,687.5 \\
\mathbf{2 , 1 4 2 . 5}\end{array}$ \\
\hline $\begin{array}{l}\text { 5. Fresh sap } \\
\text { Plastic container (20 lt capacity) }\end{array}$ & 21 pes & 100 & 2,100 \\
\hline
\end{tabular}

*at PhP90/m-day 